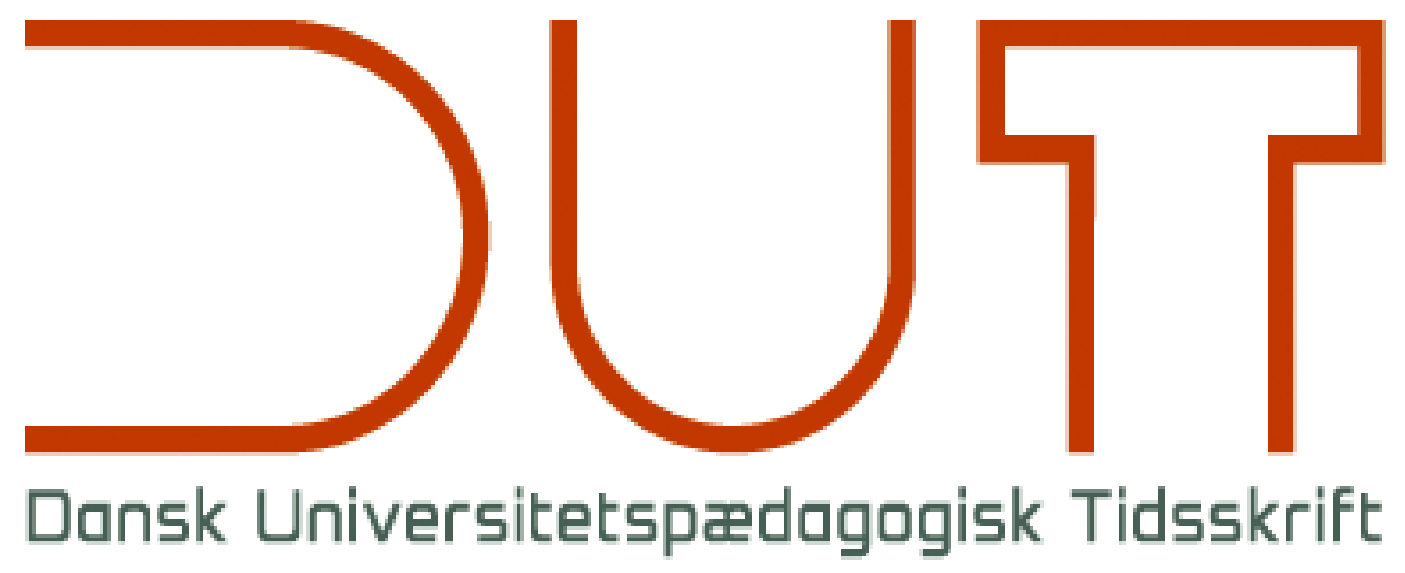

Universitetspædagogikum

Årgang 13 nr. 25 / 2018

Titel

Forfattere

Sidetal

Viden i Verden

Vibeke Andersson og Helene Balslev Clausen

3-17

Udgivet af

Dansk Universitetspædagogisk Netværk, DUN

URL

> http://dun-net.dk/

Betingelser for brug af denne artikel

(C) Copyright
Denne artikel er omfattet af ophavsretsloven, og der må citeres fra den. Følgende betingelser skal dog være opfyldt:

- Citatet skal være i overensstemmelse med "god skik"

- Der må kun citeres „i det omfang, som betinges af formålet“

- Ophavsmanden til teksten skal krediteres, og kilden skal angives ift. ovenstående bibliografiske oplysninger.

DUT og artiklens forfatter 


\section{Viden i Verden}

Vibeke Andersson, lektor, Institut for Kultur og Globale Studier (SAMF), Aalborg Universitet Helene Balslev Clausen, lektor, Institut for Kultur og Globale Studier (HUM), Aalborg Universitet

\section{Videnskabelig artikel, fagfællebedømt}

I marts 2017 tog vi til Cuba med 17 kandidatstuderende fra 'Turisme' på Aalborg Universitet. Forløbet var en del af 'Creative Learning Camp', som var en integreret del af 8. semester på kandidatuddannelsen. I forløbet blev de studerende stillet over for en opgave sat af en amerikansk NGO om boredygtig turisme $i$ Viñales, Cuba, som de skulle løse, og som de skulle levere til organisationen efter deres feltarbejde. Vi diskuterer i denne artikel, hvordan det at tage de studerende ud af undervisningslokalet til en for dem ukendt kontekst kan gøre deres laring anderledes og relevant for et senere arbejdsliv, da de skulle løse en opgave 'fra det virkelige liv' kombineret med det at skulle begå sig i en helt ny kontekst. Vi er inspireret af Kolbs laeringscirkel (2014), og vi diskuterer både peer learning og loering i grupper inden for denne teoretiske ramme. Vores antagelse er, at loeringsprocesserne styrkes inden for PBL, hvis man inddrager en erfaringsbaseret og eksperimenterende loring $i$ en virkelighedsncer kontekst. Vi betragter $i$ denne sammenhweng de studerende som både medforskere og konsulenter.

\section{Introduktion}

"Vi havde nogle antagelser før vi tog til Cuba. En forståelse af Cuba. Men da vi kom ind $i$ konteksten der, så var vi nødt til at tilpasse os på en radikal måde - ikke bare små andringer, men en helt ny måde at taenke på, og det var godt. Det hjalp os med at forme vores semesterprojekt." (Studerende E, 30. marts 2017) ${ }^{1}$

Citatet er fra en studerende, da han blev interviewet om, hvordan det at være på Cuba havde influeret på hans læringsproces og hans projektarbejde. Vi har i forbindelse med de studerendes feltarbejde studeret deres læring før, under og efter opholdet i Viñales. Vores forskningsspørgsmål er: Bliver erfaringsbaseret loering understøttet af, at de studerende kommer ud i loeringsrum, der er anderledes end universitetets? Ved at tage de studerende med i et andet læringsrum, end det der findes inden for universitets mure, bringes der aspekter i spil, som vi vil diskutere i denne artikel; samskabelse og peer learning og hvad der sker i mødet med 'den anden'. Ydermere diskuterer vi, hvordan den erfaringsbaserede og den eksperimenterende læring indgår i en proces (Kolb 2014). Vores argument er, at mødet med den anden, og i denne

\footnotetext{
${ }^{1}$ Alle interviews er oprindelig foretaget på engelsk, da gruppen af studerende er international
} 
artikel det sociokulturelle, politiske økonomiske møde med en anden, har betydning for og påvirker den måde, hvorpå de studerende lærer, både individuelt, i grupper og af hinanden. 'Den anden' (other) er et centralt begreb inden for antropologien (Eriksen 1994:33), og det er i forståelsen af 'den anden, 'at forståelsen af en selv og ens position, i dette tilfælde som turismeforsker - og konsulent - i Viñales, bliver synlig. Mødet med 'den anden' skaber altså både en forståelsesproces og en forskningsproces i en dynamisk udvikling.

Der var flere formål for de studerende med studieturen til Cuba: Dels skulle de løse en konkret opgave stillet af en amerikansk NGO, hvor fokus på bæredygtighed var centralt, og opgaven skulle løses som en konsulentopgave; dels kunne de studerende samle data ind til brug i deres 8. semester-projekter. Desuden var ideen, at de studerende skulle kunne være 'medforskere' og generere data, som både de og vi kunne bruge i vores forskning.

På Turismeuddannelsen bruger man, som på andre uddannelser på Aalborg Universitet, problembaseret læring (PBL) (Kolmos \& Krogh 2002). Vi diskuterer her, hvordan og hvorfor læringen kan styrkes ved at kvalificere studerendes refleksioner og erfaringer med at være i felten i en ny kontekst med både et akademisk og et praktisk mål for øje. Desuden diskuterer vi, hvordan det kan lede til, at studerende i højere grad end ellers tager ansvar for deres egen læringsproces.

\section{Teoretisk udgangspunkt}

Vi er inspirerede af Kolbs og Deweys begreb 'experiential learning' (Kolb 2014 (1984); Dewey, 1938; Atkinson and Murrell 1988, Kolb and Kolb 2009; Chemi and Krogh 2017), som vi oversætter som 'eksperimenterede læring'. Vi vælger at tage vores udgangspunkt i feltet mellem 'active experimentation' og 'concrete experience' i vores brug af Kolbs læringsspiral (fig 1). Fordi det netop skal forstås som en spiral (Kolb 2014), argumenterer vi for, at man kan tage udgangspunkt andre steder end i 'concrete experience', som man oftest gør i analyser af læringsprocesser. Med dette analytiske greb åbner vi op for en anderledes analyse af læringsspiralen. Desuden lægger vi vægt på kontekst, et element, som vi mener er mere eller mindre fraværende i Kolbs læringsspiral. 


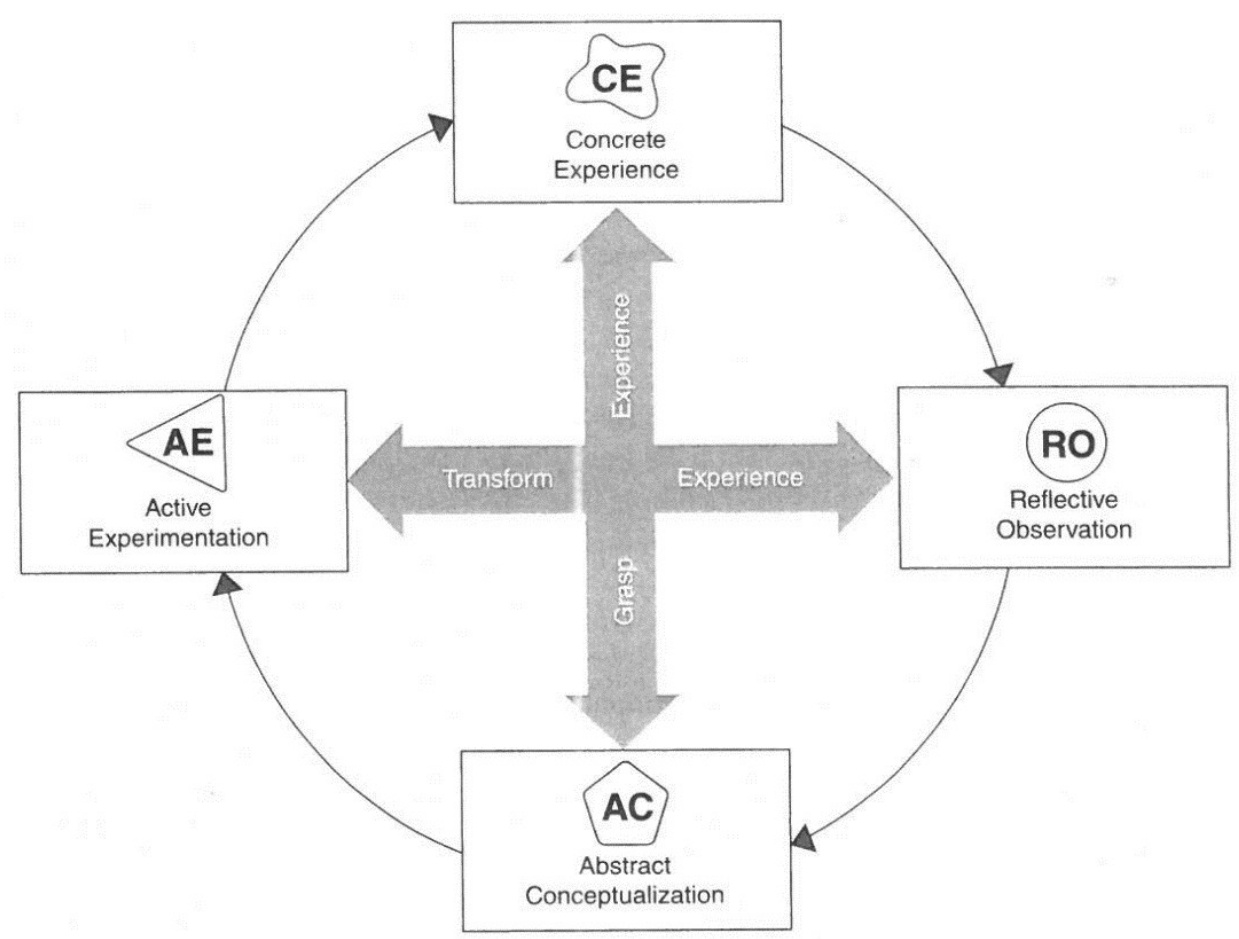

Fig 1. Kolbs læringsmodel (2014:51)

Vi vil analysere, hvordan teori om læringsprocesser kan udfordre og kvalificere PBLmodellen, og vi fokuserer på læring i grupper. For at lære i grupper, af og med hinanden, er det nødvendigt at skabe et læringsrum, hvor der er plads til dialog, udveksling af viden og erfaringer med og mellem gruppens medlemmer. PBL- modellen, som er brugt på Aalborg Universitet, skaber dette rum. Vi argumenterer for, at rummet kan udfordres ved at ændre på kontekst, og man får dermed skabt nye rum, der giver mulighed for nye refleksioner blandt de studerende.

Læring inden for problembaseret læring er baseret på, at de studerende selv tager initiativer i forhold til læringsprocessen. I casen tog vi de studerende ud af universitets læringsrum, hvilket er et af formålene med PBL; de studerende skal arbejde med emner, der tager deres udgangspunkt i et 'problem' i en sammenhæng, som skal løses praktisk og analytisk. PBL er at lære, 'hvordan man gør' i modsætning til at 'lære om' (Blichfeldt, Kvistgaard \& Hird 2017). Desuden er PBL karakteriseret ved at være interdisciplinær, hvilket er et vigtigt element, da den analyse og de løsninger, som de studerende finder frem til, ligner det, de kommer ud til, når de har afsluttet deres uddannelse og skal arbejde inden for deres felt (Bosman \& Dredge 2014; Gomez-Lanier 2017; Chemi \& Krogh 2017).

Kolbs læringsteori er blevet kritiseret for, at den er alt for omfattende: "Part of the broad attraction of the cycle is that it accommodates both deductive (moving from abstract concepts to testing their implications) and inductive (concrete experience leading to reflective practice) approaches to theory in [..] education, thereby provid- 
ing a bridge over the divide between objectivity and subjectivity, positivism and phenomenology" (Vince 1998:306). Kolb imødekommer en del af kritikken $i$ anden udgave af bogen 'Experiential Learning' (2014), hvor han samtidig argumenterer for, at læringscirklen stadig har gyldighed, hvilket vi er enige i. Kolb argumenterer i højere grad for en spiral som illustration af læringsprocessen (2014:61), i stedet for at tænke processen som en cirkel der gentager sig. Ved at bruge spiralen som billede argumenterer Kolb for, at for hver gang læringsprocessen illustreret i cirklen er fuldført, starter man på et andet niveau end det tidligere, og dermed er der en forskel $\mathrm{i}$ den erfaring, der ligger til grund for processen i forhold til observation, abstrakt tænkning og aktive eksperimenter (se fig. 1).

Kolbs læringsteori er også blevet kritiseret for, at den i for høj grad beskæftiger sig med individets læring og det psykologiske aspekt ved læringen (Illeris 2007). Kolb har i senere arbejder taget højde for denne kritik (Kolb \& Kolb 2009; Kolb 2014), hvor sociale aspekter bliver indarbejdet i den oprindelige læringscirkel fra 1984. Vi vil imidlertid bruge Kolbs pointe om læring som proces, hvor det at eksperimentere og reflektere i læringsprocessen indarbejdes i en proces, der leder læringen videre.

Vi vil diskutere 'co-creation of knowledge' og læring i grupper (Kolb \& Kolb 2009:52; Kolmos \& Krogh 2002; Egelung Holgaard, 2017). Co-creation oversætter vi med samskabelse (Thøgersen 2011; Ulrich 2016). Thøgersen diskuterer samskabelse af engagement i studieforløbet (2011). Vi bruger også begrebet samskabelse til at indfange engagement, men vi bruger 'engagement' som et element i den samskabelse af viden, som vi diskuterer i vores case.

Agger \& Tortzen diskuterer, at 'co-creation' og 'co-production' ofte bruges i flæng i forskningslitteratur (2015:11), og at begreberne især er brugt inden for politologien og sociologien til at analysere samfundsforhold og velfærdsstat (kommuner). Vi vil imidlertid bruge begrebet 'samskabelse' (co-creation) til at diskutere, hvordan læring kan opnås inden for og imellem grupper af studerende, og ved læring fra og med peers.

Samskabelse indebærer en proces, hvor forskellige aktører udvikler noget nyt sammen (Ulrich 2016). Det adskiller sig fra samarbejde ved at det, der bliver resultatet af en fælles proces, er noget andet, som ikke ville kunne skabes af individuelle aktører hver for sig. Samskabelse og kontekst vil være nøglebegreber i det følgende. Disse begreber vil blive brugt for at kunne diskutere vores case, hvor vi argumenterer for, at nye undervisningsmetoder og et anderledes læringsrum, kan skabe en anden læring for studerende.

\section{Metode}

Vi har anvendt antropologisk metode i vores forskning, idet vi både har været deltagere og observatører. Vi havde delt rollerne imellem os, så den ene stod for den 
praktiske opgave med at facilitere felten for de studerende ved at have kontaktet centrale aktører på forhånd, for at de studerende kunne komme i gang med deres (forholdsvis korte) feltarbejde. Den anden af os var primært selv på feltarbejde ved at observere de studerende i deres læringsproces. Feltarbejdet bestod i deltagerobservation og interviews med de studerende før, under og efter opholdet i Cuba samt interviews efter præsentationerne for den amerikanske NGO og den cubanske ambassadør og efter deres projekteksamen i juni.

Vi interviewede de 17 Turisme-studerende inden afrejsen om deres forventninger til deres læring i forhold til at skulle arbejde i Cuba. Vi lavede disse indledende interviews for at kunne følge og analysere den proces, som de studerende gennemgik $\mathrm{i}$ det, som vi kalder erfaringsbaseret og eksperimenterende læring. De spørgsmål, vi stillede, var åbne: a) Hvad er dine forventninger til forløbet på Cuba? b) Nævn 5 nøgleord, som beskriver din viden om Cuba. c) Beskriv tre måder, hvorpå du vil engagere dig i forløbet (Creative Learning Camp).

I Cuba samlede vi de studerende hver eftermiddag til opsamlingsmøder, hvor de præsenterede de udfordringer, de var stødt på i løbet af dagen. De præsenterede foreløbige resultater, og de delte data og oplysninger med hinanden, da alle havde et godt indblik i, hvad de andre grupper arbejdede med. Vi optog og transskriberede disse eftermiddagsmøder. Vi har selv samtidig afgrænset vores rolle i forhold til de studerende, så vi ikke blev aktive deltagere i deres projekter. Da de studerende efter nogle dage selv ændrede rolle fra studerende og turister til forskere, blev vores rolle ændret fra at være (styrende) undervisere til at være ressourcepersoner, som de kunne gå til, hvis de havde behov for det. Det er en vigtig pointe inden for PBL, at underviseren i projektarbejdet er vejleder (Kolmos \& Krogh 2002).

De studerende havde inddelt sig i grupper efter forskningsinteresse. Grupperne var dem, der afleverede konsulentrapporten, og som præsenterede den for den cubanske ambassadør ved et seminar i København nogle uger efter opholdet på Cuba. Vi interviewede de studerende efter fremlæggelsen for ambassadøren. Vores spørgsmål var igen brede for at give plads til de studerendes egne refleksioner: a) Hvad lærte du ved at præsentere for ambassadøren i dag? b) Hvordan har din læringsproces været fra starten af 8. semester frem til præsentationen i dag? c) Hvad gjorde opholdet på Cuba for din læringsproces?

De studerende afleverede nogle måneder senere deres semesterprojekt, og de gik til mundtlig gruppe-eksamen på baggrund af projekterne i juni. Efter eksamen interviewede vi de studerende igen: a) Synes du, at du har fået nye kompetencer og/eller forståelser i tiden efter præsentationen for ambassadøren og frem til eksamen i dag? b) Har du fået nogle kompetencer, du kan bruge i din fremtidige karriere? c) Hvilke (faglige) udfordringer har du haft i dette semester?

Alle interviews er blevet transskriberet. 
Som det fremgår, har vi som forskere været en del af processen igennem hele forløbet. Vi har også til dels styret læringsprocesserne, og derfor er vi måske ikke uden bias, i forhold til hvilke konklusioner vi drager af vores forskning. Imidlertid er en del af formålet at samskabe resultaterne med studerende (de er med-forskere). Vi bygger på et teoretisk fundament, og vi er samtidig bevidste om vores rolle som både deltagere og forskere (sammen med vores studerende).

\section{Beskrivelse af case}

Som beskrevet tidligere er der forventning om en høj grad af ansvar og selvstyring hos de studerende i PBL-modellen. Denne udfordres yderligere, når vi tager de studerende ud i en kontekst, der ikke umiddelbart er kendt for dem. De studerende var en gruppe af både internationale og danske Turisme-studerende, og 5 af dem talte spansk. De studerendes bevidsthed om deres egen baggrund øgedes betydeligt, da de kom på feltarbejde i en for dem ukendt kontekst og i mødet med den 'anden'. Deres nye roller som forskere og konsulenter skabte andre læringsprocesser, som de studerende ikke havde forventet inden afrejsen til Cuba.

“... Vi troede, at vi ville komme der og lave vores undersøgelser, så vi ville kunne fortaelle cubanerne, hvordan 'rigtig turismeindustri' skulle se ud, men i virkeligheden loerte vi mere, end vi kunne loere dem. Det var meget anderledes, end vi havde forventet på forhånd." (Studerende K, 6. juni 2017)

Vores argument for at udfordre de studerende ved at rejse til Cuba og give dem både en konsulentopgave og en akademisk opgave er, at det er vigtigt at uddanne kandidater, der opnår kvalifikationer, der kan bruges i deres arbejdsliv (GomezLanier 2017). Skridtet fra rollen som studerende til rollen som færdig kandidat i arbejde faciliteres ved at anvende erfaringsbaseret læring. Ved at de studerende blev mødt med uventede udfordringer i felten, som skulle løses praktisk og metodisk, idet der skulle afleveres et produkt inden for en bestemt tidsramme til samarbejdspartneren (den amerikanske NGO), øgede de deres bevidsthed om, hvad det er, der skal til for at kunne bruge deres kompetencer forhold til praktiske opgaver. I stedet for at bringe arbejdsmarkedets aktører ind på universitetet bragte vi de studerende ud i verden og opfordrede dem til at 'tænke ud af boksen' i deres forslag til den amerikanske NGO og i forhold til indsamling af data til semesterprojekter. I og med at de var i en for dem så fremmed kontekst som Cuba, og i og med at de skulle lave projektstyring, blev de udfordret på en måde, som ikke er mulig i et undervisningslokale eller inden for universitetets fysiske rammer (Smith, Levi, Saniga \& Stickells 2017).

Loerings-set-up

Før afrejsen til Cuba havde de studerende deltaget i kurser i teoretiske og metodiske emner, som de kunne bruge i deres arbejde. Vi havde kontaktet forskellige aktører i byen, hvor de studerendes arbejde skulle finde sted. Dette kan måske opfattes som 
en lidt for styrende proces, når man tænker på, at undervisningsformen ligger inden for PBL. Men det var nødvendigt af praktiske årsager. De studerende havde kun 10 dage til deres arbejde i Cuba, hvorfor vi som ressourcepersoner valgte at facilitere adgangen til nogle ressourcer, som f.eks. på forhånd at have forberedt nogle af de statslige turismeaktører på, at der ville komme nogle studerende og interviewe dem. Dette også set i lyset af ikke blot den korte tidsramme for de studerendes feltarbejde, men også det politiske system i Cuba, da flere aktører ellers ville skulle indhente tilladelser hos turistministeriet for at få lov til at tale med de studerende. Viñales er et UNESCO-beskyttet naturområde og derfor også et attraktivt turistområde, som den cubanske regering investerer $\mathrm{i}$, og flere af aktørerne talte derfor engelsk.

Da de studerende kom tilbage til Danmark, afleverede de en konsulentrapport til den amerikanske NGO om bæredygtig turismeudvikling i Viñales, som organisationen havde efterspurgt. Desuden holdt de et oplæg for den cubanske ambassadør og konsul på Aalborg Universitet, ved et seminar hvor de studerende kunne dele deres resultater med ambassadøren. Det, at de studerende skulle aflevere en konsulentopgave til den amerikanske NGO, og at de skulle præsentere deres forslag om bæredygtig turisme til ambassadøren, gjorde, at de fik en fornemmelse af, hvad det vil sige at skulle interagere med forskellige typer af aktører uden for universitetsverdenen. Dette gav mulighed for at generere erfaringer og kompetencer hos de studerende, som de kan tage med sig i deres fremtidige arbejdsliv.

Vi bruger vores delresultater (for eksempel dem fra Cuba) i vores undervisning løbende. På den måde bliver forsknings- og læringsprocessen for de studerende sammenvævede i en kontinuerlig proces (Chemi \& Krogh 2017), hvor processen for de studerende er, at den viden, der opnås via samarbejde og dialog, bliver omsat til erfaring (Dewey 1938; Kyed \& Pedersen 2016; Kjær-Rasmussen \& Jensen 2017), der kan bruges både i kommende universitetsprojekter og i arbejdslivet efter universitetet.

Vi har brugt tre af de studerende, som var på Cuba, som studenterundervisere på et 9. semester-forløb, og vi har kunnet samle op på, hvordan læringsprocessen har været for studenterunderviserne, samtidig med at vi kunne skabe nye undervisningsformer sammen med de studerende ved at inddrage dem til at undervise deres peers.

\section{Resultater og diskussion}

\section{Peer learning}

De studerendes læring under opholdet i Cuba var mangesidig. De lærte ikke kun fra de erfaringer og refleksioner på erfaringer, de fik individuelt, som er indeholdt i Kolbs læringsspiral (2014). De lærte også ved at dele deres erfaringer og ved at arbejde i grupper, hvor de delte deres oplevelser og resultater med alle de andre stu- 
derende ved de eftermiddagssessioner, vi havde hver dag. Som illustration af dette sagde en studerende efter at være kommet tilbage til Danmark:

"Det er første gang, jeg har samarbejdet på denne her måde. Det er ikke den første gang, jeg har indsamlet mit eget data, men første gang, jeg har arbejdet sammen med så stor en gruppe, hvor alle arbejdede med det samme emne. Folk indsamlede forskellige typer data, diskuterede det, og man kunne reflektere over, hvordan det er blevet fortolket og opfattet af forskellige mennesker." (Studerende $H, 30$. marts 2017)

Vi argumenterer for, at netop konteksten og samskabelse af viden styrkede de studerendes læringsprocesser på en ny måde, som skaber en platform for Kolbs erfaringsbaserede læring (Kolb 2014). Her tænker vi ikke blot på den cubanske kontekst, men også konteksten i form af, at de alle havde det samme felt, som de fik noget forskelligt ud af, og derfor blev de inspirerede af hinanden og hinandens resultater.

Vi observerede dette under eftermiddagssessionerne, hvor de studerende efter nogle dage gennemgik en proces, hvor de begyndte at reflektere over deres observationer i stedet for at referere dem. De begyndte at bruge begreber, de var blevet præsenteret for i undervisningen inden afrejsen til Cuba, på nye og innovative måder. I den proces fik de sammen analyseret sig frem til nye indsigter ved at udveksle viden og forståelser med hinanden og hinandens feltarbejde i en fælles læringsproces. De studerende betragtede sig selv som 'turister' de første dage under opholdet i Viñales. Dette blev tydeligt, fordi de studerende kommenterede og beskrev deres oplevelser i felten som 'gode' og 'dårlige' oplevelser, og vi kunne se, at det materiale, de studerende indsamlede og diskuterede de første dage, alle havde lige gyldighed. Efterhånden begyndte de at reflektere over deres materiale og gruppere det i forhold begreber og teoretisk ramme. Noget blev vigtigere end andet, og begreberne pegede på, hvad der var vigtigt, og hvad der ikke var. I de interviews, vi lavede, efter de var kommet tilbage til Danmark, bemærkede de studerende selv, hvordan de var gået igennem en proces, hvor de havde bevæget sig fra at være observatører ('turister') til forskere. De kunne selv se, hvordan de gradvist begyndte at bruge teorier og begreber, når de diskuterede deres feltobservationer med hinanden. Deres læringskurve steg dramatisk, fordi de delte deres resultater og skabte læring indbyrdes.

De studerendes viden og analyse kom op på et andet abstraktionsniveau gennem læringsprocessen (Kolb 2014; Kolb and Kolb 2009; Vince 1998, Gomez-Lanier 2017). De kunne bygge på de analytiske færdigheder, de havde opnået i Cuba, efter de kom tilbage til Danmark, hvor de brugte deres materiale i både konsulentrapporter og semesterprojekter. I overvejelserne over, hvorvidt 'problemstillinger fra det virkelige liv' betød noget for de studerende og deres læring, siger en af de studerende:

"Jeg ville svare 'ja', for vi havde mulighed for at arbejde mere med vores projekt og toenke over, hvad der kunne vore relevant for os og for analysen ved hjoelp af teo- 
rierne. Derfor andrede vi faktisk vores teorivalg og fandt frem til vores problemformulering. Vi endte med at aendre den grundloeggende idé bag projektet." (Studerende L, 16. juni 2017)

\section{Kontekstens betydning}

Mens vi var på Cuba, kunne vi se, at det ville være nødvendigt at introducere de studerende for mere teori, som var relateret til Cuba. Vi organiserede en 'miniforelæsning' om udviklingsperspektivet, specielt alternativ udvikling og lokal deltagelse, eftersom nogle af de studerende var udfordret af, at de ikke havde begreber, de kunne anvende. Vi ser dette som en del af PBL processen, selvom nogle måske kunne argumentere for, at det var for styrende. Imidlertid argumenterer vi for, at det var en del af en proces af samskabelse af viden, som kunne løfte de studerendes abstraktionsniveau i den konkrete situation. Disse små 'skub' fra os som ressourcepersoner kunne være med til at åbne felten for de studerende, som udtrykt her:

"Man er nødt til at opleve destinationen for at forstå: 'Hvad er det for et sted?', 'hvem er de her folk?', 'hvad er situationen?'. Uden at forstå konteksten kan man på ingen måde begynde at skabe noget, for eksempel et produkt eller en rapport." (Studerende C, 15. juni 2017)

Vores observationer ligner dem, som Gomez-Lanier (2017) finder i sin case. Hun tager designstuderende med til New York og Kina, hvor de møder centrale aktører inden for design-feltet. Hun beskriver, hvordan studieture øger de studerendes refleksionsniveau.

Vi argumenterer for, at studerende, hvis de får en konkret opgave, som de skal aflevere efterfølgende til en aktør uden for universitetsverdenen, lærer selv at arbejde med analytiske begreber i en konkret kontekst. Da vi spurgte en studerende efter semesteret, om det havde hjulpet med til at opnå færdigheder, blev der svaret:

"Ja. Arbejdet med vores semesterprojekt har fået os til at reflektere over, hvordan PBL-tilgangen har påvirket projektet, vores arbejde, de indsamlede data, vores forforståelse osv. Så vi har varet i kontakt med konteksten, både imens vi var på Cuba, og imens vi lavede vores analyse." (Studerende E, 15. juni 2017)

Som beskrevet før så er interdisciplinær læring en central del af PBL, og det er vigtigt for de studerendes opnåelse af viden (Bosman \& Dredge 2014). En studerende udtrykker det således:

"Jeg har fået en større forståelse for, at alle fag og emner, som vi har arbejdet med $i$ løbet af de sidste to semestre, indgår i en hvilken som helst karriere, som man kan forfølge. Man kan ikke sige: 'Jeg vil kun arbejde med policy' - alt vil voere en del af det. Så man kan godt vaelge et fokusområde, men det er nødvendigt at have en bred viden om alle emnerne." (Studerende C, 15. juni 2017) 


\section{Erfaringsbaseret loering}

Vidensdeling indgår i, hvad Kolb \& Kolb kalder 'deep learning' (2005). Læringsprocessen er i 'deep learning' netop en proces, hvor der er flere 'trin' og dermed flere erkendelser, der fører til en ny slags læringsproces. Vi har tidligere anført, at vi observerede, hvordan de studerende gik fra at opfatte sig selv som 'turister' til at opfatte sig selv som forskere. Dette kan ses af citatet her:

"Vi snakkede om forskellige forventninger. Eksempelvis i forhold til turene, hvor vi forventer en tur på to timer, men får en tur, som varer fire timer. For dem virker det som en god service, men for os kan det voere irriterende. Der kan voere forskellige forventninger til, hvad turisten egentlig vil have, og hvad vaerten tror, at turisten vil have." (Studerende B, gruppediskussion 7. marts 2017)

Den type læringsproces, som den studerende giver udtryk for her, er svær at opnå i undervisningslokalet og til forelæsninger, også selvom man inviterer aktører fra 'det virkelige liv' indenfor på universitetet. Her bliver formidlingsmetoderne ofte til foredrag eller forelæsninger. Når studerende er $\mathrm{i}$ felten og arbejder med opgaver, der skal løses for forskellige modtagere (NGO og universitet), bliver deres refleksioner mere nuancerede og gennemtænkte, idet de kan se nye sider af problemstillinger, som de måske ikke ellers ville have fået øje på. Ifølge Kolb (2014) handler den erfaringsbaserede læring netop om, at de studerende skal kunne gøre sig erfaringen ved at handle og eksperimentere og ikke kun kognitivt høre og forstå. I vores case vil vi argumentere for, at de studerende 'gennemlever' de forskellige dimensioner i Kolbs læringsspiral, og at dette giver et løft i læringen. Vores argument er her, at ikke kun feltarbejde (som er en integreret del af for eksempel antropologien) er nødvendigt for at indsamle materiale ved hjælp af forskellige metoder, men også at det at blive sat i en ny kontekst kan føre til, at læringsprocessen kvalificeres. Dermed kunne man sætte et element mere ind i Kolbs læringsspiral, nemlig kontekst: 


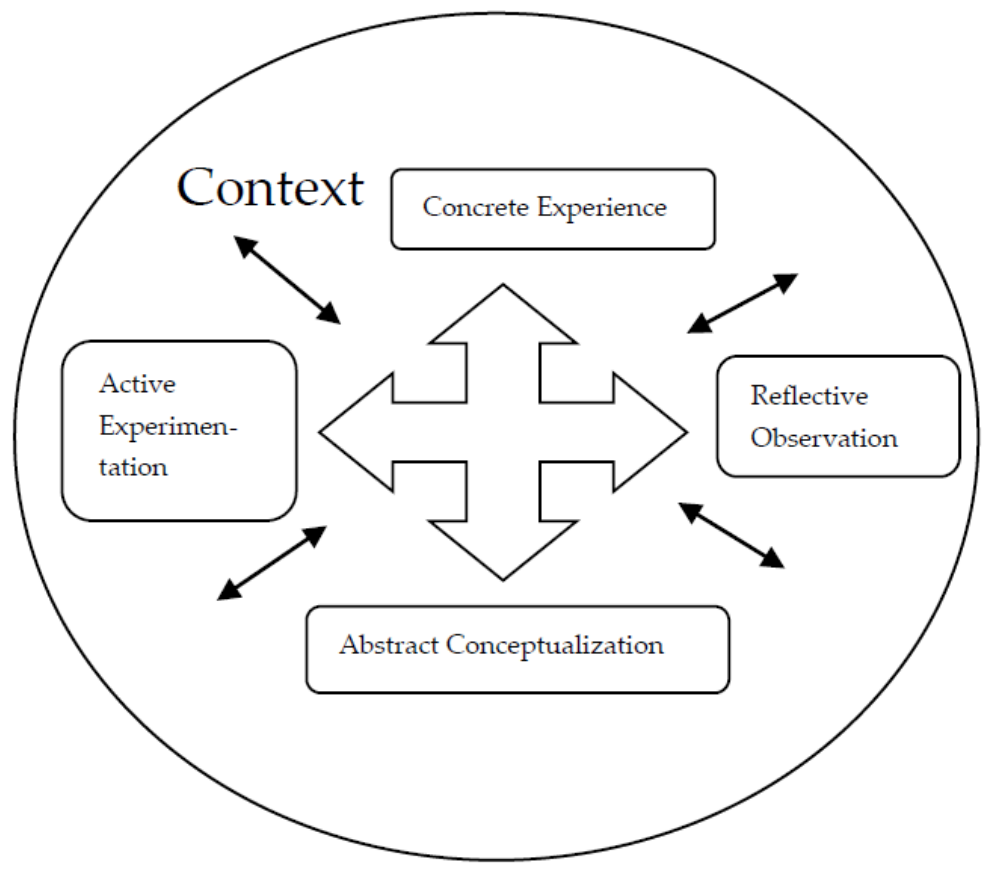

Figur 2. Eksperimentel og erfaringsbaseret læring, inspireret af Kolb (2014)

Der er andre former for konkret læring forbundet med vores case; den korte tid før afleveringen af en konsulentopgave giver de studerende en ide om, hvad det vil sige at arbejde med projektstyring, noget, som de vil møde i deres arbejdsliv. Denne metode kan være med til at skabe sammenhæng mellem universitet og arbejdsliv (Gomez-Lanier 2017; Yorke 2006). To studerende udtrykker det på denne måde:

"Opholdet i Cuba var den mest laererige oplevelse på 8. semester, og det gav os mulighed for at se, at teorien ikke altid passer på virkeligheden. Jeg loerte mere af denne oplevelse, end jeg gjorde af kun at vore til undervisningen." (Studerende K, 30. marts 2017)

og

"Vi fik en masse viden, som man ikke kan finde i litteraturen eller slå op. Vi fik også erfaring med, hvor vigtigt det er altid at voere så 'lokal' som muligt og at interagere med de lokale. Eftersom vores research omhandlede Casas Particulares (Bed and Breakfast) og lokalsamfundet, var det meget givtigt at vore til stede og vore en del af lokalsamfundet." (Studerende J, 30. marts 2017)

Som det ses af et af citaterne ovenfor, så kan de studerende se nødvendigheden af at kunne benytte teorier til 'problemer' i det virkelige liv på en anden måde efter at have været i Cuba. Vores argument er, at fordi de skulle løse en konsulentopgave, samtidig med at de kunne samle materiale ind til deres universitetsprojekt, fik de en større forståelse for de forskellige former for viden, som det at være i en ny kontekst kan åbne for. De bliver mere parate til at indgå på arbejdsmarkedet, hvilket universiteter har stigende fokus på i disse år. PBL og erfaringsbaseret læring er gode redskaber til at skabe koblingen mellem studie og arbejdsliv, og vi har 'udvidet' PBL til 
også at blive brugt inden for en helt ny kontekst, som er fremmed for de studerende, og som de skal forholde sig til via de færdigheder, de har opnået ved at arbejde med PBL tidligere i deres uddannelse. Nøglefærdigheder og kernekompetencer er essentielle for universitetsuddannelser. Disse opnås i høj grad ved undervisning inden for universitets mure. Vi argumenterer i lighed med andre (Bosman \& Dredge 2014, Blichfeldt et al 2017, Gomez-Lanier 2017) for, at færdigheder opnås bedst, hvis de studerende også bruger dem uden for universitetet, og med opgaver der ligner dem, de skal løse i deres arbejdsliv. Når vi lægger så stærk vægt på at tage de studerende ud, så afspejles det også i det, de studerende siger om deres oplevelse af opholdet i Cuba:

"Det cendrede tingene. Det fremhoevede virkelig vigtigheden af kontekst, for man kan loese en masse tekster, men man kan ikke nødvendigvis anvende dem i alle situationer." (Studerende J, 30. marts 2017)

De studerende opnåede et mere holistisk perspektiv på kompleksiteten i at studere bæredygtig turisme i Viñales:

"Jamen, den første [udfordring] er, som allerede noevnt, at teorien ikke passer på Cuba, og dét var det primaere problem i løbet af hele processen. Vi var nødt til konstant at gentcenke og udvide teorierne, så de blev mere brugbare - og samtidig vare kritiske hele tiden. Jeg tror, at dét var den største udfordring." (Studerende D, 15. juni 2017)

og

"At arbejde med de konkrete cases, finde en fremgangsmåde og tilpasse sig til casene og konteksterne. Dét tror jeg vil voere en brugbar foerdighed senere hen, for man får måske en masse idéer, når man sidder ved et skrivebord og laver teoretisk arbejde, men når man så møder en kontekst, er man nødt til at loere at tilpasse sig den, arbejde med den og passe på den." (Studerende E, 15. juni 2017)

Vi erfarede, hvordan de studerende tog ansvar som en gruppe og imellem dem selv, så vores rolle langsomt skiftede fra at være undervisere til at være ressourcepersoner. De studerende tog aktivt ansvaret for deres egen læring, og de blev gode til at samskabe viden og dele deres resultater grupperne imellem - til gavn for alle studerende.

\section{Konklusion}

Vi spurgte i vores forskningsspørgsmål, om erfaringsbaseret læring bliver understøttet af, at de studerende kommer ud i læringsrum, der er anderledes end universitetets. Vi tog studerende ud i verden, i en kontekst som er helt fremmed for dem, og spørgsmålet er, om det øger og kvalificerer deres læring. Ifølge en af de studerende, der var med, så er det i høj grad tilfældet: 
"Ja, for på universitetet arbejder vi hovedsageligt med bceredygtighedsteori, mens vi på Cuba loerte, hvordan det faktisk fungerer i virkeligheden. Det gjorde vi ved at tale med de lokale om bceredygtighed, skrive projektet, undersøge policies og arbejde med den viden, som vi fik på Cuba. Jeg loerte, hvor vigtigt det er at arbejde bottom-up og inkludere lokalsamfundets medlemmer i beslutningsprocesserne." (Studerende M, 15. juni 2017)

Vores analyse har vist, at studerende i høj grad lærer ved at være involverede og dermed motiverede til at lære, som Kolb viser i sin læringsspiral (2014). Studerende lærer imidlertid ikke kun individuelt, men i grupper, og det at være i grupper øger både vidensdeling, den kritiske refleksion og samskabelse af viden.

Det at indsamle sit eget materiale giver ikke kun færdigheder i at arbejde empirisk. Det giver også færdigheder i kritisk at skulle udfolde en metode og arbejde med teori:

"Jeg synes, at en meget vigtig del af vores semesterprojekt er metodeafsnittet. Ikke på grund af den traditionelle metodologi, som vi loerer om fra bøger, men dét at kunne forklare på en akademisk måde, hvordan det rent faktisk foregår, når man er $\mathrm{i}$ felten. Det er fint at sidde derhjemme og loese om, hvordan man udfører et interview eller laver deltagerobservation, men man opdager, at alting cendrer sig, når man befinder sig $i$ en anderledes kulturel kontekst." (Studerende H, 5. juni 2017)

Engagement og motivation er en væsentlig forudsætning for læringsprocesserne i en kontekst, der er ukendt for de studerende. Når der stilles krav til, eller der er forventninger fra de andre studerende om, at alle bidrager og samskaber, vil de ofte være mere engagerede, og resultatet af deres arbejde bliver bedre og mere kritisk reflekterende. Vi har været inspirerede af Kolbs læringsspiral. Vi har udbygget den med et lag af 'kontekst' omkring cirklen, og vi har argumenteret for, at læring i grupper giver en anden form for læring, end den individuelle læring som Kolbs model oprindelig opererede med. På trods af dette mener vi, at det giver mening at bruge Kolb i en PBL-sammenhæng, da de forskellige elementer i cirklen, som gentages og dermed danner en spiral, er et af kernefundamenterne i den problembaserede læring eller den erfaringsbaserede og eksperimentelle læring. Kolbs ideer kan derfor kvalificere PBL-tilgangen, når man tilføjer kontekst som et vigtigt element, som vi har gjort det i figur 2. I stedet for at de studerende henter cases fra 'det virkelige liv', som man ofte gør i PBL-modellen, så tager vi et skridt videre og flytter hele undervisningen ud i verden (et andet læringsrum), og lader de studerende agere der i deres læringsproces. Det specielle ved vores kontekst er, at den ud over at være 'derude' også er i en anden kulturel kontekst. Dette presser de studerende til at forholde sig til den anden, en anden kultur, og det giver dem en ekstra dimension i deres læring, idet man i mødet med den anden lærer om sig selv (Eriksen 1994). 


\section{Referencer:}

Agger, A. \& Tortzen, A. (2015). Forskningsreview om samskabelse. University College Lillebælt.

Atkinson, G. \& Murrell, P.H. (1988). Kolb's Experiential Learning Theory: A MetaModel for Career Exploration. I: Journal of Counseling \& Development, 66, (8), 374-377

Blichfeldt, B. S., Kvistgaard, P. \& Hird, J.. (2017). Teaching Tourism Change Agents. In: Innovative Practice in Higher Education, 3 (1), 48-64

Bosman, C. \& Dredge, D. (2014). Teaching about tourism in a post-disciplinary planning context. I: Dredge Dianne; David Airey \& Michael J. Gross (eds) The Routledge Handbook of Tourism \& Hospitality Education. Chapter 20. London: Routledge.

Bornstein, D. \& Davis, S (2010). Social Entrepreneurship. What everyone needs to know. Oxford University Press

Chemi, T. \& Krogh, L. (eds). (2017). Co-Creation in Higher Education. Students and Educators Preparing Creatively \& Collaboratively to the Challenge of the Future. Rotterdam: Sense Publishers.

Dewey, J. (2015) (1938). Experience \& Education. New York, N.Y: Free Press

Eriksen, T. H. (1994). Små Steder, store spørgsmål. Innføring i sosialantropologi. Universitetsforlaget Oslo, 2. opplag

Egelund Holgaard, J., Dahms, M. Kolmos, A \& Guerra, A. (2017).Empowering students to co-construct the PBL environment. I: Guerra, A., Rodriguez, F. J., Kolmos, A., \& Reyes, I. P. (red) (2017). PBL, Social Progress and Sustainability.

Aalborg: Aalborg University Press. (International Research Symposium on PBL).

Gomez-Lanier, L. (2017). The Experimental Learning Impact of International and Domestic Study Tours: Class Excursions That are More Than Field Trips. I: International Journal of Teaching \& Learning in Higher Education 29 (1), 129-144.

Illeris, K. (2007). Laring. Roskilde: Roskilde Universitetsforlag, 2. reviderede udg.

Keeton, M. T., Sheckley, B. G., \& Griggs, J. K. (2002). Efficiency and effectiveness in higher education. Dubuque: Kendall/Hunt Publishing Company.

Kjær-Rasmussen, L. K. \& Jensen A.A.(2017) Student Development Dialogue: A method for supporting students' reflections and professional development in Higher Education (Open Access ed.) Aalkborg Universitetsforlag. Higher Education Series No.4

Kolb, D.A. (2014 (1984)). Experiential Learning: Experience as the source of learning and 
development. Pearson Education Inc. NJ. Second edition

Kolb, A. Y. \& Kolb, D.. (2005). Learning Styles and Learning Spaces: Enhancing Experiential Learning I: Higher Education: Academy of Management Learning \& Education, 4 (2) 193-212.

Kolb, A. Y. \& Kolb, D.. (2009). Experiential Learning Theory: A Dynamic, Holistic Approach to Management Learning, Education \& Development. In: Armstrong, S. J \& Fukami, C.V.: The Sage Handbook of Management Learning, Education \& Development, chapter 3 (s. 42-69) London: Sage.

Kolmos, A. (1996): Reflections on Project Work \& Problem-based Learning. In: European Journal of Engineering Education, 21, (2), 141-148.

Kolmos, A. \& Krogh, L. (2002). Projektpœedagogik i udvikling. Pædagogisk Udviklingscenter, Aalborg: Aalborg Universitet.

Kolmos, A., Krogh, L., Fink, F.K. (red). (2004). The Aalborg PBL model: progress, diversity \& challenges. Aalborg: Aalborg University Press.

Kyed, M. \& Pedersen, L.M. (2016). Gruppebaserede øvelser - en empirisk analyse af muligheder og udfordringer. I: Dansk Universitetspaedagogisk Tidsskrift, 21, 1-13.

Smith, W., Lewi, H., Saniga, A., Stickells, L. \& Constantindis, D. (2017). Bringing the Classroom into the World. In: Journal of Problem Based Learning in Higher Education. 5 (1).

Thøgersen, U. (2011). Samskabelse af engagement - om fastholdelse af de studerendes deltagelse i undervisning. I: Dansk Universitetspaedagogisk Tidsskrift, 10, 45-51.

Ulrich, J. (2016). Samskabelse - en Typologi. I: Clou Skriftserie 1, 1-16. Via University College

Vince, R. (1988). Behind \& beyond Kolb's Learning Cycle. I: Journal of Management Education, 22 (3), 304-19

Wood, G. (2016). Voices from the Field: Developing Employability Skills for Archaelogical Students Using a Project Based Learning Approach I: Journal of Problem Based Learning 4 (1), 100-108.

Yorke, M. (2006). Employability in Higher Education. Berlin: Raabe Academic Publishers.

Yorke, M. \& Knight, P.T.. (2006). Embedding Employability in the Curriculum. Learning \& Employability Series 1 Online: https://www.heacademy.ac.uk/system/files/id460 embedding_employability in to the curriculum 338.pdf 